(OSTI ID: 807525)

\title{
INCREASED OIL PRODUCTION AND RESERVES UTILIZING SECONDARY/TERTIARY RECOVERY TECHNIQUES ON SMALL RESERVOIRS IN THE PARADOX BASIN, UTAH (Contract No. DE-FC22-95BC14988)
}

\section{ANNUAL REPORT February 9, 2001 - February 8, 2002}

Thomas C. Chidsey, Jr., Principal Investigator

Submitted by

Utah Geological Survey

Salt Lake City, Utah 84114-6100

March 2002

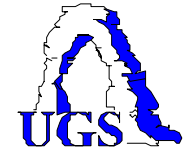

Contracting Officer's Representatives

Gary D. Walker/Dan Ferguson

U.S. Department of Energy

National Petroleum Technology Office

P.O. Box 3628

Tulsa, OK 74101 


\section{DISCLAIMER}

This report was prepared as an account of work sponsored by an agency of the United States Government. Neither the United States Government nor any agency thereof, nor any of their employees, makes any warranty, express or implied, or assumes any legal liability or responsibility for the accuracy, completeness, or usefulness of any information, apparatus, product, or process disclosed, or represents that its use would not infringe privately owned rights. Reference herein to any specific commercial product, process, or service by trade name, trademark, manufacturer, or otherwise does not necessarily constitute or imply its endorsement, recommendation, or favoring by the United States Government or any agency thereof. The views and opinions of authors expressed herein do not necessarily state or reflect those of the United States Government or any agency thereof. 


\title{
INCREASED OIL PRODUCTION AND RESERVES UTILIZING SECONDARY/TERTIARY RECOVERY TECHNIQUES ON SMALL RESERVOIRS IN THE PARADOX BASIN, UTAH (Contract No. DE-FC22-95BC14988) \\ ANNUAL REPORT
}

Thomas C. Chidsey, Jr., Principal Investigator

Submitted by

Utah Geological Survey

Salt Lake City, Utah 84114-6100

March 2002

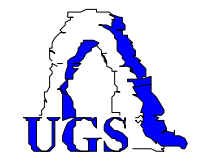

Contract Date: February 9, 1995

Anticipated Completion Date: August 31, 2005

Government Award (fiscal year): $\$ 1,420,919$

Program Manager/Principal Investigator: Thomas C. Chidsey, Jr.

\author{
Contracting Officer's Representatives \\ Gary D. Walker/Dan Ferguson \\ U.S. Department of Energy \\ National Petroleum Technology Office \\ P.O. Box 3628 \\ Tulsa, OK 74101
}

Reporting Period: February 9, 2001 - February 8, 2002

US/DOE Patent Clearance is not required prior to the publication of this document. 


\section{CONTENTS}

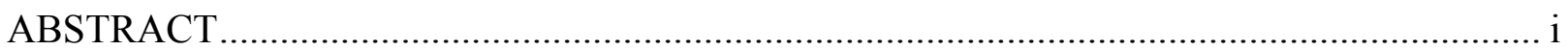

EXECUTIVE SUMMARY ....................................................................................... ii

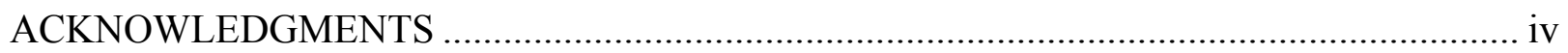

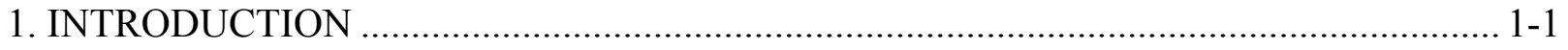

2. IMPLEMENTATION OF PILOT CARBON DIOXIDE FLOOD DEMONSTRATION .... 2-1

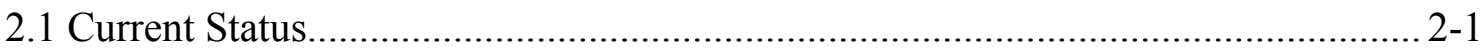

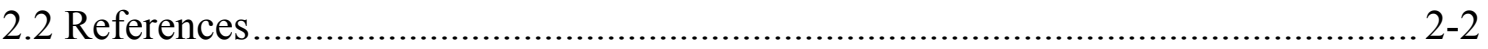

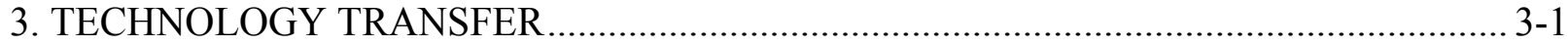

3.1 Utah Geological Survey Petroleum News, Survey Notes, and Internet Web Site.... 3-1

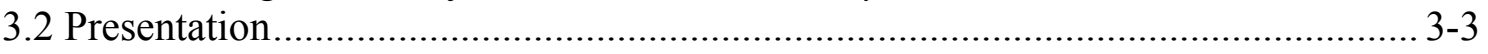

3.3 Project Publication ............................................................................... 3-3

\section{FIGURES}

Figure 1.1. Location of project fields............................................................................ 1-1

Figure 3.1. The Paradox Basin project page from the UGS Internet web site....................... 3-2 


\section{ABSTRACT}

The Paradox Basin of Utah, Colorado, and Arizona contains nearly 100 small oil fields producing from carbonate buildups or mounds within the Pennsylvanian (Desmoinesian) Paradox Formation. These fields typically have one to four wells with primary production ranging from 700,000 to $2,000,000$ barrels $\left(111,300-318,000 \mathrm{~m}^{3}\right)$ of oil per field at a 15 to 20 percent recovery rate. At least 200 million barrels $\left(31,800,000 \mathrm{~m}^{3}\right)$ of oil is at risk of being unrecovered in these small fields because of inefficient recovery practices and undrained heterogeneous reservoirs. Five fields (Anasazi, Mule, Blue Hogan, Heron North, and Runway) within the Navajo Nation of southeastern Utah were evaluated for waterflood or carbon-dioxide $\left(\mathrm{CO}_{2}\right)$-miscible flood projects based upon geological characterization and reservoir modeling. Geological characterization on a local scale focused on reservoir heterogeneity, quality, and lateral continuity as well as possible compartmentalization within each of the five project fields. The results can be applied to other fields in the Paradox Basin and the Rocky Mountain region, the Michigan and Illinois Basins, and the Midcontinent region.

Simulation of Anasazi field has shown that a $\mathrm{CO}_{2}$ flood is technically superior to a waterflood and economically feasible. The key to increasing ultimate recovery from the field (and similar fields in the basin) is to design a $\mathrm{CO}_{2}$-miscible flood project capable of forcing oil from high-storage-capacity but low-recovery supra-mound units into the high-recovery moundcore units. For Anasazi field, an optimized $\mathrm{CO}_{2}$ flood is predicted to recover a total 4.21 million stock tank barrels $\left(0.67\right.$ million $\left.\mathrm{m}^{3}\right)$ of oil representing in excess of 89 percent of the original oil in place.

Based on the simulation results, Anasazi field was chosen as the best candidate for a pilot $\mathrm{CO}_{2}$-flood pilot demonstration project. The field demonstration includes: obtaining a $\mathrm{CO}_{2}$ source and fuel gas (for the compressor), conducting a $\mathrm{CO}_{2}$ injection test(s), rerunning project economics, drilling a development well(s) (vertically or horizontally), purchasing and installing injection facilities, monitoring field performance, and validating and evaluating the techniques.

The only $\mathrm{CO}_{2}$ line in the area, which is owned and operated by ExxonMobil, is currently operating at full capacity supplying $\mathrm{CO}_{2}$ to wells on the north side of the San Juan River as part of a large $\mathrm{CO}_{2}$ flood of the giant Greater Aneth field. Plans to expand the pipeline capacity and extend it to Greater Aneth wells south across the river, and thus closer to Anasazi field, were delayed about a year and a half due to low oil prices in 1998 and early 1999, and a backlog of higher priority projects of the Greater Aneth field operators. These factors, combined with uncertainty related to the merger of Mobil and Exxon, have delayed the availability of $\mathrm{CO}_{2}$ for the Anasazi field demonstration for at least three years. All project fields (Anasazi, Blue Hogan, Heron North, Mule, and Runway) operated by the Utah Geological Survey's industry partner, Harken Energy Corporation, have been sold to the Rim Energy Companies of Denver, Colorado. Rim Energy is currently having difficulty obtaining APDs and approved right-of-ways due to assignability problems with the Navajo Nation. Ultimately when completed, the demonstration will prove (or disprove) $\mathrm{CO}_{2}$-flood viability, and thus help determine whether the technique can be applied to the other small carbonate buildup reservoirs throughout the Paradox Basin.

Technology transfer during the seventh project year consisted of booth display at a national professional convention, a technical presentation, publications, newsletter, and a project home page on the Internet. 


\section{EXECUTIVE SUMMARY}

The primary objective of this project is to enhance domestic petroleum production by field demonstration and technology transfer of an advanced-oil-recovery technology in the Paradox Basin, southeastern Utah. If this project can demonstrate technical and economic feasibility, the technique can be applied to approximately 100 additional small fields in the Paradox Basin alone, and result in increased recovery of 150 to 200 million barrels $(23,850,000$ $31,800,000 \mathrm{~m}^{3}$ ) of oil. This project is designed to characterize five shallow-shelf carbonate reservoirs in the Pennsylvanian (Desmoinesian) Paradox Formation and choose the best candidate for a pilot demonstration project for either a waterflood or carbon-dioxide- $\left(\mathrm{CO}_{2}-\right)$ miscible flood project. The field demonstration, monitoring of field performance, and associated validation activities will take place within the Navajo Nation, San Juan County, Utah.

The Utah Geological Survey (UGS) leads a multidisciplinary team to determine the geological and reservoir characteristics of typical, small, shallow-shelf carbonate reservoirs in the Paradox Basin. The Paradox Basin project team consists of the UGS (prime contractor) and several subcontractors. This research is performed under the Class II Oil Program of the U.S. Department of Energy, National Petroleum Technology Office (NPTO) in Tulsa, Oklahoma. This report covers research and technology transfer activities for the seventh project year (February 9, 2001 through February 8, 2002).

Reservoir simulations were completed on both the Anasazi and Runway project fields during Phase I. The key to increasing ultimate recovery from these fields (and similar fields in the basin) is to design a $\mathrm{CO}_{2}$-miscible flood project capable of forcing oil from high-storagecapacity but low-recovery supra-mound units into the high-recovery mound-core units. Simulation of Anasazi field showed that a $\mathrm{CO}_{2}$ flood is technically superior to a waterflood, and economically feasible. For Anasazi field, an optimized $\mathrm{CO}_{2}$ flood is predicted to recover a total 4.21 million stock tank barrels $\left(0.67\right.$ million $\left.\mathrm{m}^{3}\right)$ of oil. This represents an increase of 1.65 million stock tank barrels $\left(0.26\right.$ million $\left.\mathrm{m}^{3}\right)$ of oil over predicted primary depletion recovery as of January 1, 2012. The projected 4.21 million stock tank barrels of oil production represents in excess of 89 percent of the original oil in place.

Based on the simulation results, Anasazi field was chosen as the best candidate for a pilot $\mathrm{CO}_{2}$-flood pilot demonstration project. The field demonstration includes: obtaining a $\mathrm{CO}_{2}$ source and fuel gas (for the compressor), conducting a $\mathrm{CO}_{2}$ injection test(s), rerunning project economics, drilling a development well(s) (vertically or horizontally), purchasing and installing injection facilities, monitoring field performance, and validating and evaluating the techniques.

At this time, there is only one $\mathrm{CO}_{2}$ source in the area, a pipeline that is owned and operated by ExxonMobil. The $\mathrm{CO}_{2}$ line is currently operating at full capacity supplying $\mathrm{CO}_{2}$ to wells on the north side of the San Juan River as part of a large $\mathrm{CO}_{2}$ flood of the giant Greater Aneth field. Plans to expand the pipeline capacity and extend it to Greater Aneth wells south across the river, and thus closer to Anasazi field, were delayed about a year and a half due to low oil prices in 1998 and early 1999, and a backlog of higher priority projects of the Greater Aneth field operators. These factors, combined with uncertainty related to the merger of Mobil and Exxon, have delayed the availability of $\mathrm{CO}_{2}$ for the Anasazi field demonstration for at least three years.

All project fields (Anasazi, Blue Hogan, Heron North, Mule, and Runway) operated by the Utah Geological Survey's industry partner, Harken Energy Corporation, have been sold to the 
Rim Energy Companies of Denver, Colorado. Rim Energy is currently having difficulty obtaining APDs and approved right-of-ways due to assignability problems with the Navajo Nation. However, the Utah Geological Survey still desires to see the project completed through the demonstration phase, and will continue to carefully monitor the $\mathrm{CO}_{2}$ availability and assignability situations. Ultimately when completed, the demonstration will prove (or disprove) $\mathrm{CO}_{2}$-flood viability, and thus help determine whether the technique can be applied to the other small carbonate buildup reservoirs in the Paradox Basin.

Technology transfer during the seventh project year consisted of displaying project materials at the UGS booth during the national convention of the American Association of Petroleum Geologists. In addition, one technical presentation was made to the Industry/Bureau of Land Management/County Work Group. Project team members published quarterly and annual reports, and a newsletter detailing project progress and results. The UGS maintains a home page for the Paradox Basin project on the Internet. 


\section{ACKNOWLEDGMENTS}

This research is performed under the Class II Oil Program of the U.S. Department of Energy (DOE), National Petroleum Technology Office, Tulsa, Oklahoma, contract number DEFC22-95BC14988. The Contracting Officer's Representatives/Project Managers are Gary D. Walker and Dan Ferguson. Additional funding was provided by Harken Southwest Corporation, Houston, Texas; and the Utah Energy Office.

\section{Project Contributors:}

Principal Investigator/Program Manager:

T.C. Chidsey, Jr.; Utah Geological Survey, Salt Lake City, UT

Financial Officers:

John Kingsley, Dan Kelly; Utah Geological Survey, Salt Lake City, UT

Contributing Scientists and Organizations:

R.L. Bon, T.C. Chidsey, Jr., K.P. McClure; Utah Geological Survey, Salt Lake City, UT

D.E. Eby; Eby Petrography \& Consulting, Inc.; Littleton, CO

Utah Geological Survey Petroleum News was edited by Roger Bon. Jim Parker (Utah Geological Survey) drafted figures. Cheryl Gustin (Utah Geological Survey) desktop-published and assembled reports.

This report was reviewed by Dave Tabet, Mike Hylland, and Kimm Harty, Utah Geological Survey, and Viola Schatzinger and Dan Ferguson, National Petroleum Technology Office, U.S. Department of Energy. 


\section{INTRODUCTION}

Over 400 million barrels $\left(63,600,000 \mathrm{~m}^{3}\right)$ of oil have been produced from shallow-shelf carbonate reservoirs in the Pennsylvanian (Desmoinesian) Paradox Formation in the Paradox Basin of Utah, Colorado, and Arizona. With the exception of the giant Greater Aneth field, 100plus oil fields in the basin typically contain 2 to 10 million barrels $\left(318,000-1,590,000 \mathrm{~m}^{3}\right)$ of original oil in place per field. To date, none of these small fields have been the site of tertiary carbon dioxide $\left(\mathrm{CO}_{2}\right)$ flood recovery techniques used in large carbonate reservoirs. Most of these fields are characterized by extremely high initial production rates followed by a very short production life (primary), and hence early abandonment. At least 200 million barrels $\left(31,800,000 \mathrm{~m}^{3}\right)$ of oil is at risk of being left behind in these small fields because of inefficient recovery practices and undrained heterogeneous reservoirs. The purpose of this multi-year project is to enhance domestic petroleum production by field demonstration and technology transfer of an advanced-oil-recovery technology in the Paradox Basin.

The benefits expected from the project are: (1) increasing recoverable reserves by identifying untapped compartments created by reservoir heterogeneity, (2) increasing deliverability through a carbon-dioxide- $\left(\mathrm{CO}_{2}-\right)$ miscible flood which exploits the reservoir along optimal fluid-flow paths, (3) identifying reservoir trends for field extension drilling and stimulating exploration in Paradox Basin fairways, (4) preventing premature abandonment of numerous small fields, (5) reducing development costs by more closely delineating minimum field size and other parameters necessary to a successful flood, (6) allowing limited energy investment dollars to be used more productively, and (7) increasing royalty income to the Navajo Nation; Federal, State, and local governments; and fee owners. These benefits also apply to other areas in the Rocky Mountain region, the Michigan and Illinois Basins, and the Midcontinent.

The geological and reservoir characteristics of five fields (figure 1.1) that produce oil and gas from the Desert Creek zone of the Paradox Formation were quantitatively determined by a multidisciplinary team. Anasazi field was chosen as the best candidate for a pilot $\mathrm{CO}_{2}$-flood demonstration project after reservoir simulations were completed on both the Anasazi and Runway fields. To evaluate these fields as models for other shallow-shelf carbonate reservoirs, the Utah Geological Survey (UGS), Harken Southwest Corporation, Eby Petrography \& Consulting Inc., and REGA Inc. entered into a cooperative agreement with the U.S. Department of Energy (DOE) as part of its Class II Oil

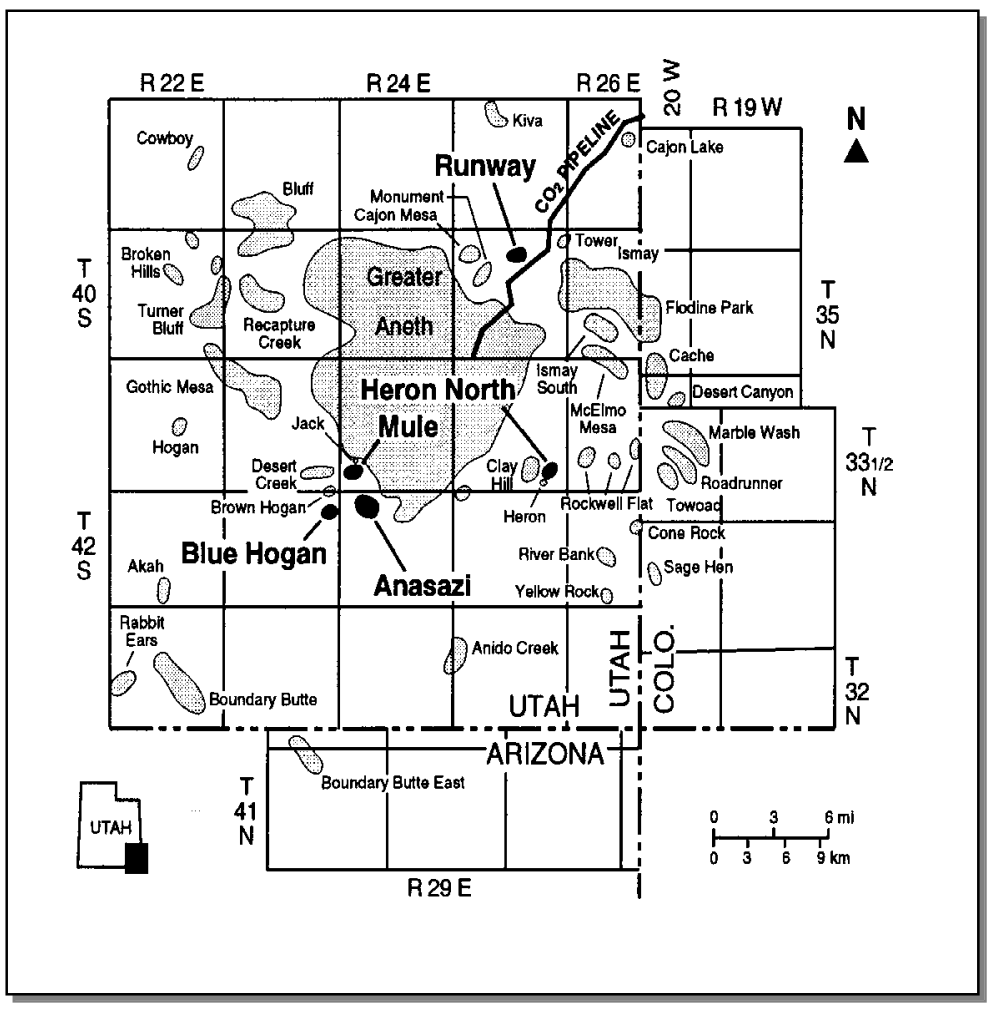

Figure 1.1. Location of project fields (dark shaded areas with names in bold type) in the southwestern Paradox basin on the Navajo Nation, San Juan County, Utah. 
program. However, in 2001 all project fields (Anasazi, Blue Hogan, Heron North, Mule, and Runway [figure 1.1]) operated by Harken were sold to the Rim Energy Companies of Denver, Colorado. The UGS has no contract with Rim Energy at this time.

A two-phase approach is being used to increase production and reserves from the shallow-shelf carbonate reservoirs in the Paradox Basin. Phase I was the geological and reservoir characterization of the five small fields. Work completed during this phase of the project included:

(a) field data collection and compilation,

(b) determination of diagenetic fabrics and porosity types found in the various hydrocarbon-bearing rocks of each field,

(c) field-scale geologic analysis to focus on the reservoir heterogeneity, quality, and lateral continuity versus compartmentalization,

(d) reservoir geostatistical modeling,

(e) history matching and reservoir $\mathrm{CO}_{2}$-flood and waterflood simulations,

(f) field reserves and secondary/tertiary recovery determination,

(g) economic assessments of $\mathrm{CO}_{2}$ floods for Anasazi and Runway fields, and

(h) recommendation of plans for pilot flood implementation and production scenarios for Phase II, the field demonstration project.

Phase II is a demonstration project on Anasazi field, which was selected from the characterization study, using a $\mathrm{CO}_{2}$-miscible flood. This technique was identified as having the greatest potential for increased well productivity and ultimate recovery. The demonstration project will include:

(a)

(b)

(c)

(e) acquiring a $\mathrm{CO}_{2}$ source for the flood project,

acquiring a fuel gas source for the compressor,

conducting a $\mathrm{CO}_{2}$ injection test(s),

rerunning project economics,

drilling a development well(s), vertically or horizontally, to facilitate sweep during the pilot flood,

purchasing and installing injection facilities, 
(g)

flood management, monitoring field performance, and evaluation of results, and

(h) determining the application of the project to similar fields in the Paradox Basin and throughout the U.S.

The results of this project are being transferred to industry and other researchers through a petroleum extension service, creation of digital databases for distribution, technical workshops and seminars, field trips, technical presentations at national and regional professional meetings, maintaining a project home page on the Internet, and publication in newsletters and various technical or trade journals.

This report is organized into three sections: (1) Introduction, (2) Implementation of Pilot Carbon Dioxide Flood Demonstration, and (3) Technology Transfer. This report presents the status of the demonstration and is not intended as a final report. Whenever possible, preliminary conclusions have been drawn based on available data. 


\section{IMPLEMENTATION OF PILOT CARBON DIOXIDE FLOOD DEMONSTRATION}

\subsection{Current Status}

Results from Budget Period I of this project showed that a $\mathrm{CO}_{2}$ flood was technically superior to a waterflood and was economically feasible on typical small, shallow-shelf carbonate buildup reservoirs in the Paradox Basin (Chidsey and Allison, 1998; Chidsey and others, 1999). Based on the geologic characterization study, reservoir performance predictions, and the associated economic assessment of implementing a $\mathrm{CO}_{2}$ flood in the Anasazi field, San Juan County, Utah (figure 1.1), an optimized $\mathrm{CO}_{2}$ flood is predicted to recover 4.21 million stock tank barrels (STB) $\left(0.67\right.$ million $\left.\mathrm{m}^{3}\right)$ of oil. This represents an increase of 1.65 million STB $(0.26$ million $\mathrm{m}^{3}$ ) of oil over predicted primary depletion recovery at January 1, 2012. If the $\mathrm{CO}_{2}$ flood performs as predicted, it is a financially robust process for increasing the reserves of the Anasazi field and similar small fields in the basin.

Budget Period II of the project involves the implementation of a pilot $\mathrm{CO}_{2}$-flood demonstration on Anasazi field. The field demonstration includes: obtaining a $\mathrm{CO}_{2}$ source and fuel gas for the compressor, conducting a $\mathrm{CO}_{2}$ injection test(s), rerunning project economics, drilling a development well(s) (vertically or horizontally), purchasing and installing injection facilities, monitoring field performance, and validation and evaluation of the techniques. The demonstration will prove (or disprove) $\mathrm{CO}_{2}$-flood viability and thus help determine whether the technique can be applied to the other small carbonate buildup reservoirs in the Paradox Basin. Obtaining a $\mathrm{CO}_{2}$ source is the key to beginning this demonstration.

At this time, there is only one $\mathrm{CO}_{2}$ source in the area, a pipeline (figure 1.1) which is owned and operated by ExxonMobil (formerly Mobil Oil Corporation). The $\mathrm{CO}_{2}$ line is currently operating at full capacity supplying $\mathrm{CO}_{2}$ to wells on the north side of the San Juan River as part of a large $\mathrm{CO}_{2}$ flood of the giant Greater Aneth field. In 2000, 15.5 billion cubic feet $(\mathrm{BCF})\left(0.44\right.$ billion $\left.\mathrm{m}^{3}\right)$ of $\mathrm{CO}_{2}$ was injected into the Desert Creek reservoir (Paradox Formation) in the field (Cordova, 2002). During the year, monthly injection of $\mathrm{CO}_{2}$ averaged 0.4 BCF (11.2 million $\mathrm{m}^{3}$ ). Plans to expand the pipeline capacity and extend it to Greater Aneth wells south across the river, and thus closer to Anasazi field, were delayed about a year and a half due to low oil prices in 1998 and early 1999, and a backlog of higher priority projects of the Greater Aneth field operators. These factors, combined with uncertainty related to the merger of Mobil and Exxon, and current low oil prices, have delayed the availability of $\mathrm{CO}_{2}$ for the Anasazi field demonstration for at least three years. However, the pipeline has now been extended south of the San Juan River to other parts of Greater Aneth field and futher expansion is planned. In recent discussions with the UGS, ExxonMobil has expressed interest in providing $\mathrm{CO}_{2}$ for the demonstrations project and working with the operator of surrounding fields.

In 2001, all project fields (Anasazi, Blue Hogan, Heron North, Mule, and Runway) operated by the UGS's industry partner, Harken Energy Corporation, were sold to the Rim Energy Companies of Denver, Colorado. Rim is currently having difficulty obtaining APDs and approved right-of-ways due to assignability problems with the Navajo Nation. However, the UGS still desires to see the project completed through the demonstration phase, and will continue to carefully monitor the $\mathrm{CO}_{2}$ availability and assignability situations. The UGS 
established contact with the Rim Energy Companies. A meeting between Rim Energy and nonUGS project team members in Denver to review the project results and objectives occurred on September 11, 2001. Due to the tragic events of that day, Tom Chidsey, the Principal Investigator, was unable to fly to the meeting from Salt Lake City. He will meet separately with Rim Energy at a later date to determine their interest in continuing the pilot demonstration.

Several operators of other fields in the Paradox Basin similar to Anasazi have expressed interest in the technique and would consider conducting the $\mathrm{CO}_{2}$-flood project with DOE/UGS support if problems prevent the demonstration from occurring at Anasazi field. Most operators in the basin are small independent companies that need to see a successful and economically viable $\mathrm{CO}_{2}$-flood demonstrated on a small field before they will invest in $\mathrm{CO}_{2}$ acquisition, new pipelines, injection wells, and additional field facilities.

\subsection{References}

Chidsey, T.C., Jr., and Allison, M.L., 1998, Increased oil production and reserves utilizing secondary/tertiary recovery techniques on small reservoirs in the Paradox Basin, Utah annual report for the period February 9, 1998 to February 8, 1999: U.S. Department of Energy, DOE/BC/14988-10, 66 p.

Chidsey, T.C., Jr., Eby, D.E., Lorenz, D.M., and Culham, W.E., 1999, Increased oil production and reserves utilizing secondary/tertiary recovery techniques on small reservoirs in the Paradox Basin, Utah - annual report for the period February 9, 1998 to February 8, 1999: U.S. Department of Energy, DOE/BC/14988-12, 47 p.

Cordova, Lisha, 2002, Utah annual injection report 2000: Utah Division of Oil, Gas and Mining, in preparation. 


\section{TECHNOLOGY TRANSFER}

The UGS is the Principal Investigator and prime contractor for five government-industry cooperative petroleum-research projects, including two in the Paradox Basin. These projects are designed to improve recovery, development, and exploration of the nation's oil and gas resources through use of better, more efficient technologies. The projects involve detailed geologic and engineering characterization of several complex heterogeneous reservoirs. The Class II Paradox Basin (the project for this report and Class Revisit project) and the Class I Bluebell field (Uinta Basin) projects include practical oil-field demonstrations of selected technologies. The fourth project involves geological characterization and reservoir simulation of the Ferron Sandstone on the west flank of the San Rafael uplift as a surface analogue of a fluvial-dominated, deltaic reservoir. The fifth project involves establishing a log-based correlation scheme for the Tertiary Green River Formation in the southwestern Uinta Basin to help identify new plays and improve the understanding of producing intervals. The DOE and multidisciplinary teams from petroleum companies, petroleum service companies, universities, private consultants, and state agencies are co-funding the five projects.

The UGS will release all products of the Paradox Basin project in a series of formal publications. These will include all the data as well as the results and interpretations. Syntheses and highlights will be submitted to refereed journals as appropriate, such as the American Association of Petroleum Geologists (AAPG) Bulletin and Journal of Petroleum Technology, and to trade publications such as the Oil and Gas Journal. This information will also be released through the UGS periodicals Petroleum News and Survey Notes, and on the project Internet home page.

Project publications, materials, plans, and objectives were displayed at the UGS booth during the AAPG Annual Convention, June 3-6, 2001, in Denver, Colorado. Three to four UGS scientists staffed the display booth at this event. Project displays will be included as part of the UGS booth at meetings throughout the duration of the project.

\subsection{Utah Geological Survey Petroleum News, Survey Notes, and Internet Web Site}

The purpose of the UGS Petroleum News newsletter is to keep petroleum companies, researchers, and other parties involved in exploring and developing Utah energy resources, informed of the progress on various energy-related UGS projects. Petroleum News contains articles on: (1) DOE-funded and other UGS petroleum project activities, progress, and results, (2) current drilling activity in Utah including coalbed methane development, (3) new acquisitions of well cuttings, core, and crude oil at the UGS's Utah Core Research Center (formerly referred to as the Geological Sample Library), and (4) new UGS petroleum publications. The purpose of Survey Notes is to provide nontechnical information on contemporary geologic topics, issues, events, and ongoing UGS projects to Utah's geologic community, educators, state and local officials and other decision-makers, and the public. Survey Notes is published three times yearly and Petroleum News is published annually. Single copies are distributed free of charge and reproduction (with recognition of source) is encouraged. The UGS maintains a database that includes those companies or individuals specifically interested in the Paradox Basin project (more than 300 as of February 2002) or other DOE-sponsored projects. 
The UGS maintains a web site on the Internet, http://geology.utah.gov. This site includes a page under the heading Economic Geology Program, that describes the UGS/DOE cooperative studies (Paradox Basin, Ferron Sandstone, Bluebell field, Green River Formation), contains the latest issue of Petroleum News, and has a link to the U.S. Department of Energy web site. Each UGS/DOE cooperative study also has its own separate page on the UGS web site. The Paradox Basin project page (http://geology.utah.gov.emp/PARADOX/index.htm) contains: (1) a project location map, (2) a description of the project, (3) a list of project participants and their postal addresses and phone numbers, (4) executive summaries from the Annual Reports, (5) each of the project Quarterly Technical Progress reports, and (6) a reference list of all publications that are a direct result of the project (figure 3.1).

Utah Geological Survey

\section{Paradox Basin - DOE Class II Study}

Reports

$\square$ Project description

$\checkmark$ Project participants

$\square$ First Annual Technical Report

$\square$ Second Annual Technical Report

$\square$ Quarterly Technical Progress Reports: $\square \underline{1995}$ 1st Quarterly Report

a. 1995 2nd Quarterly Report

․ 1995 3rd Quarterly Report

$\square 1995$ 4th Quarterly Report

$\square$ 1996.1st Quarterly Report

$\square 1996$ 2nd Quarterly Report

$\square 1996$ 3rd Quarterly Report

$\square \underline{19964 \text { th Quarterly Report }}$

$\square 1997$ 1st Quarterly Report

1997 2nd Quarterly Report

$\square$ 19973rd Quarterly Report

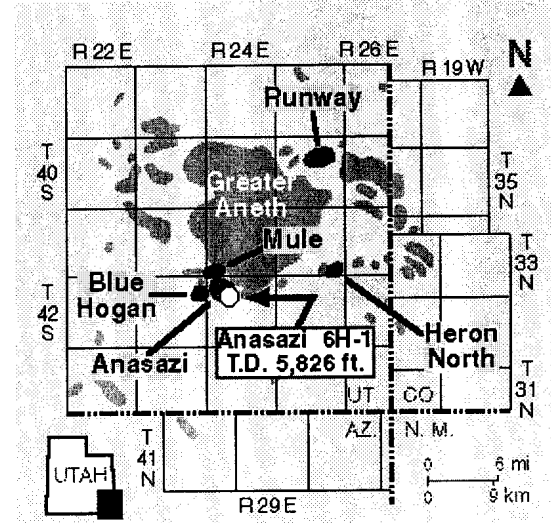

References

$\square$ Publications resulting from the study

(1. For more information on the Paradox Basin Project, contact Tom Chidsey, (801) 537-3364, email nrugg.tchidsey@state.ut.us. For copies of reports with tables and figures, contact Roger L. Bon, (801) 537-3363, email: nrugs.rbon@state.ut.us.

Bluebell Field Project / Ferron Sandstone Project Petroleum News / Economic Geology Program

UGS Home

Figure 3.1. The Paradox basin project page, http://geology.utah.gov.emp/PARADOX/index.htm, from the UGS Internet web site. 


\subsection{Presentation}

A project overview and discussion of petroleum potential in the Paradox Basin was presented by Tom Chidsey (Principal Investigator), to the Industry/U.S. Bureau of Land Management (BLM)/County Work Group, sponsored by the Utah Petroleum Association (UPA), January 24, 2002. The UPA established the Work Group to create an understanding of industry needs and better define the rules and regulations governing oil and gas exploration in the areas administered by the BLM Moab District and Price and Monticello Field Offices, central and southeastern Utah.

\subsection{Project Publication}

Chidsey, T.C., Jr., 2001, Increased oil production and reserves utilizing secondary/tertiary recovery techniques on small reservoirs in the Paradox Basin, Utah - annual report for the period February 9, 2000 to February 8, 2001: U.S. Department of Energy, $\mathrm{DOE} / \mathrm{BC} / 14988-14,20 \mathrm{p}$. 